\author{
Sara CASAGRANDE
}

\title{
UNDERSTANDING EMU ASYMMETRIES AND THEIR ECONOMIC AND POLITICAL IMPLICATIONS
}

\begin{abstract}
The Covid-19 emergency makes the seriousness of the unsolved political and economic issues that emerged during the European sovereign debt crisis even more evident. Today more than ever it is necessary to answer questions related to the fragility of the EMU architecture: why was the EMU created with an asymmetric structure? What was the role of EMU architecture and European policies during the crisis? Do EMU asymmetries threaten the survival of the Eurozone? The European integration process took place on the basis of a permissive consensus determined by the expectation of successful economic outcomes, without a true democratic legitimacy. Under such conditions, a fiscal and political union was not possible. The EMU proved to be a competitive arena, within which economic and political asymmetries were difficult to manage. An analysis of these asymmetries allows conclusions to be drawn regarding the risks associated with further economic and institutional integration.
\end{abstract}

\footnotetext{
(C) Sara Casagrande, 2021.
}

Casagrande, Sara, Dr., Department of Economics and Management, University of Trento via Inama, Italy. ORCID: 0000-0001-6205-1944 Email: sara.casagrande@unitn.it. 


\section{Key words:}

asymmetry; democracy; economic crisis; economic and institutional integration; Europe; EMU architecture; Eurozone; fiscal policy; political union.

JEL: F15, O52, P16.

70 References.

\section{Introduction}

The Covid-19 emergency is now being described as a black swan event for the world economy (Yarovaya et al., 2020). It surprised the European Union $(E U)$ at a delicate phase of its integration process, in a period marked by difficulties connected to a wave of populism, Brexit challenges, and prospects of low long-term growth. Although the health emergency is an external shock for which no member country has responsibility, it is not easy to identify a shared economic and political strategy within EU. Admittedly, the suspension of the Stability and Growth Pact (SGP), the proposal to introduce Coronabonds (a new version of the much-discussed Eurobonds, a common debt instrument) was opposed by some northern countries that continued to refuse the introduction of any risk-sharing instrument (Weber, 2020). The debates and long negotiations that accompanied the recovery package deal and the European budget in July 2020, including the strong opposition of the so-called frugal countries to the southern countries, clearly shows that the Covid-19 emergency is a new context in which the unsolved political and economic issues that emerged during the European sovereign debt crisis have to be faced once more. A narrative that contrasts the "cicadas of the south" with the "ants of the north" has come back into fashion (The Economist, 2020). This narrative played a role in the Recovery Plan debate (Masera, 2020), and is strongly connected to the fear that European resources will be wasted through irresponsible and excessive spending (Bialasiewicz, 2020). 
This paper suggests that the current situation is the result of unsolved political and economic problems related to the fragility of the asymmetrical Economic and Monetary Union (EMU) architecture. As explained by Schlosser (2019, p.2) «absent a central state, EMU's architecture has been characterised from its inception by an asymmetrical institutional design marked by the co-existence of a centralized, supranational monetary policy capacity on the one hand and decentralized, intergovernmental fiscal and economic policies constrained by EU rules, on the other». The hostility that emerged between core and the periphery countries has been recognised as a sort of "second asymmetry» (Howarth \& Verdun, 2020, p.288). This second asymmetry, closely related to power asymmetries between member countries (Eichacker, 2017), experienced a revival during the Covid-19 emergency, and should be analysed in close connection with the asymmetric institutional design of the EMU. Indeed, although the economic literature has widely discussed the asymmetrical EMU structure, there is less clarity about the theoretical and political reasons for this architecture, and its long-term socio-economic and political implications. The most controversial aspects of EMU asymmetries will be discussed in this paper via three questions: why was the EMU created with an asymmetric structure? What was the role of EMU architecture and European policies during the crisis? Do EMU asymmetries threaten the survival of the Eurozone? Clear answers to these questions are an essential prerequisite for understanding how to proceed with the integration process after the Covid-19 emergency, and the risks associated with further economic and institutional integration. Obviously, the answers offered in this paper are a simple starting point to encourage more scholars to deepen their understanding of the theoretical roots and socio-economic and political implications of EMU asymmetries.

Section 2 analyses the European political project, trying to understand the political and economic reasons that led to an EMU with an asymmetric structure. Section 3 analyses the role of EMU architecture and European policies during the crisis. Section 4 considers whether EMU asymmetries threaten the survival of the Eurozone and the risks associated with further integration. Section 5 concludes.

\section{The Reasons for an EMU with an Asymmetrical Architecture}

\section{The Federalist Project and the Role of Democracy}

The EU is the result of the widespread desire to build a new and different Europe, able to guarantee a future of peace and prosperity (Dyson \& Maes, 2016). The terrible experience of the world wars led many to consider further European integration through the greater economic integration of European countries to be fundamental, which would be achieved through exchange rate 

and their economic and political implications

stability. These important but very general objectives were the fundamental goals shared by the architects ${ }^{1}$, politicians and economists who collaborated in the development of the European integration project.

The most important debate in the first phase of this integration process was probably that between the federalist and intergovernmental schools. According to the federalist school, the only way to avoid rivalries between European countries degenerating into a war again was to incorporate those countries into a federalist structure. As noted by Baldwin and Wyplosz (2009), this position was supported by the countries that had suffered the most tragic consequences of the world wars (e.g., Austria, Germany, Italy, Belgium, the Netherlands, Luxembourg, France) and «many Europeans, including many Germans, felt that Germany would be best unified in conjunction with a big increase in the forces tying EU members together» (p. 29). On the other hand, countries that had not suffered occupation, dictatorship, and/or the most dramatic consequences of the world war (e.g., the UK, Ireland, Sweden, Iceland, Switzerland) were more likely to consider full national sovereignty a guarantee of the well-being of their nations and they promoted an integration process limited to close intergovernmental cooperation relationships. "Intergovernmentalism initially dominated the post-war architecture. In part, this was simply a matter of timing» (p. 12), indeed, the success of the European Coal and Steel Community (ECSC) in the 1950s was only the first step towards the growing influence of the federalist school which culminated in the creation of the EMU.

The EMU was a first step towards a federal economic government, but the goal of the political union was, and still remains, rather vague. The extent to which member countries will have to renounce their sovereignty, and how the competences will be divided between individual member states and the European institutions, is still not clear. In general, supporters of the European federalist project imagine political union not as the result of a centralisation process, but as a "complex multi-level parliamentary democracy» (Duff, 2011, p.4) where «the delimitation of competences between the Union and its states along with the powers of the institutions will be set out in a written constitution which will have legal supremacy» (p.5). In practical terms, the federalists hope that the single currency will be followed by fiscal union, the elimination of the last barriers to the

\footnotetext{
${ }^{1}$ Following Dyson and Maes (2016), we use the term «architects» to mean «intellectuals who had an active role in the process of designing the institutional arrangements of Economic and Monetary Union (EMU). They constitute a relatively neglected group of persons who were more than just 'technocratic' policy-makers» (p. 254). They were «not simply 'expert with influence' but 'intellectuals as policy-makers'» (p.11) able to «built up personal networks and institutional structures of support for their ideas, as both intellectuals and policy advocates» (p. 10). They included Raymond Barre, Jacques Delors, Roy Jenkins, Alexandre Lamfalussy, Robert Marjolin, Tommaso Padoa-Schioppa, Karl-Otto Pöhl, Hans Tietmeyer, Robert Triffin, and Pierre Werner (Dyson \& Maes, 2016).
} 
single market, and the construction of a European foreign, security, immigration and defence policy.

The rejection of the proposed European constitution in two separate ratification referendums in 2005, by France and the Netherlands, made it clear that European populations did not necessarily approve of the European political project. As explained by Startin and Krouwel $(2013$, p.67) «the two referendum results were not a great surprise as in recent years there has been clear evidence that a 'gap' between pro-European political leaders and a more sceptical citizenry has emerged in both countries». It is not clear whether this 'gap' was a widespread phenomenon within the EU. Indeed, only Luxembourg and Spain ratified the treaty establishing a European constitution by referendum, and the other countries approved it without popular consultation, or decided to cancel the programmed referendums. Empirical study seems to suggest that there is a gap between élites and public opinion about European integration (Hooghe, 2003), and the consequences of the French and Dutch referendums were considered devastating and largely unforeseen in the EU constitutional project (Closa, 2007).

The role of democracy in the European project is somewhat controversial. The possibility that the EU as a single body suffers from a structural democratic deficit has been the subject of debate since the origins of the European integration process. Some scholars are convinced that EU is democratically legitimate through the national elections of the representatives of the member states (Moravcsik, 2002), while others are convinced that there is a democratic deficit, although there is no unanimous definition of 'democratic deficit' (Follesdal \& Hix, 2006). Without going into the details of this debate, which was developed further after the European sovereign debt crisis, when some theorists started to talk explicitly about the Eurozone's crisis of democratic legitimacy (Schmidt, 2015), it is important to understand the real role of the European populations in the integration project.

An important aspect of the federalist approach is that it implicitly assumes that democracy is not enough to guarantee a future of peace and prosperity, and that European countries should reduce their national sovereignty. Baldwin and Wyplosz (2009, pp.11-12) describe how «some Europeans felt that national sovereignty and the nation-state constituted a fragile system prone to warfare [...]. To these thinkers, even democracy was insufficient to prevent horrifying wars. Hitler, after all, gained his first hold on power through democratic means». This incomplete confidence in democracy has led European political élites to promote an integration process beyond what is probably the true degree of awareness of the European populations. Bickerton et al. (2015, pp.709-710) note that «the early decades of European integration had benefitted from a 'permissive consensus' in which the people deferred to élites when it came to the pooling of sovereignty". This implies that European identity, on the basis of which every project of political convergence should stand, still needs to be defined. For this reason, according to Majone (2005, p.219), «the federalist project was doomed from the 

and their economic and political implications

start», basically because a European demos was absent; in other words «there was no European people to sustain such an ambition» (Hayward, 2012, p.6).

All this confirms that it would have been difficult to start the integration process relying on something more than the silent consensus of many European populations. As noted by Cerutti $(2008$, p.10) «legitimacy is easily mistaken to be consensus, which is a phenomenon not unambiguously related to it, while the legal legitimacy based upon the treaties is just a background element of political legitimacy».

\section{Legitimation, Consensus, and the Competitive Attitude}

It is well known that the European integration project did not really originate with European populations, and that «European integration is mostly pushed by élites and interest groups that transcend national boundaries» (Guiso et al., 2016, p.252). The European project was promoted by policy-makers who, in addition to the desire to avoid future conflicts, had important national economic interests. The expectation of successful economic outcomes became the source of the silent consensus of European populations. Weiler (2001, p.33) observes «the general degradation of political process within the European body politic principally by making acceptable governance legitimated by successful outcomes rather than by democratic process». Although he admits that «the European construct, democratic deficit notwithstanding, has been approved democratically again and again» (p.40), he claims that «these successful «referenda» which give a valid democratic patina to the European Community represent, too, the corrupting effect of the European success on the civic sensibilities of the European peoples and on the very meaning of what it means to be a democracy» (p.41). Weiler adds that «the fact that so regularly the European construct is approved without a serious challenge to its questionable democratic quotidian praxis represents the invasion of the market mentality into the sphere of politics whereby citizens become consumers of political outcomes rather than active participants in the political process. In this respect Europe seems to produce a negative moral «spill over» effect» (p.41).

This legitimation based on economic success has had significant repercussions for the attitudes of governments towards the European Union. Indeed, European governments, which depend on the consent of voters, have always tried to exploit their EU membership to pursue national interests, with unpredictable effects for other member countries. This behaviour is not considered particularly anomalous. As noted by Scharpf (2011, p.163), «in capitalist democracies, governments depend on the confidence of their voters. To maintain this confidence, however, they also depend on the performance of their real economies 
and, increasingly, on the confidence of financial markets». The problem with EU is that economic reasoning is at the base of its foundation. As noted by Varoufakis (2016, p.90), «Europe's union is nothing like America's, [...] it was founded as an administration for an industrial cartel, rather than as a political mechanism by which to balance competing interests in a democracy». This sort of competition revealed the absence of real shared goals beyond the pursuit of national interests. As claimed by Wilhelm Nölling, Chairman of the Hamburg Landeszentralbank until 1992, «we should be under no illusion - the present controversy over the new European monetary order is about power, influence and the pursuit of national interests» (Connolly, 1995, p.98).

The absence of true democratic legitimacy, the consensus based on economic results and the competitive attitude of the member countries played a fundamental role in the process of European integration, favouring the adoption of the single currency albeit within an unstable architecture, and although no member country was yet willing to converge towards a political union, at least in the short term.

\section{Towards Monetary Integration: Debates and Issues}

The introduction of the single currency was a fundamental binding step. The debate on monetary integration was characterised by the opposition of two approaches: the so-called monetarists and economists. As described by Maes (2002, p.67) monetarists were convinced that monetary integration would induce economic and political convergence. This position was shared mostly in France, Italy and by the European Commission. The economists emphasised the role of national heterogeneity and the need to ensure political and economic convergence before monetary integration. This vision was shared mostly by Germany and the Bundesbank, which emphasised the importance of future member states ensuring fiscal discipline, flexible markets and labour mobility. As noted by Dyson and Maes (2016, pp.19-20), monetarists gained intellectual support from the endogenous Optimal Currency Area (OCA) theory, and originated from French Colbertism, which promoted a discretional approach. Economists, instead, found support in traditional OCA theory and originated from German ordoliberalism, which promoted a rule-based approach.

The original OCA theory pioneered by Mundell (1961) and McKinnon (1963) states that a geographic area in which countries are economically similar would benefit from the introduction of a single currency, however, this is only true under certain fundamental conditions: high labour and capital mobility, price and wage flexibility, similar business cycles and shocks, production integration and the presence of a fiscal mechanism to share risk across countries. It is quite evident that 

and their economic and political implications

the European case satisfies only some of these conditions. In particular, labour mobility is low, there is a lack of any type of risk-sharing mechanism, while shocks are asymmetric and business cycles asynchronous. Despite this, OCA theory has been considered the «theoretical core of the Euro Zone» (Dan, 2014, p.72) although «the optimum currency area argument has been used both for and against the creation of the euro" (Vane and Mulhearn, 2006, p.98). Frankel and Rose (1998) clearly explained how it was possible to apply the OCA paradigm to the European case. They claim that «the OCA criteria are jointly endogenous. The suitability of European countries for EMU cannot be judged on the basis of historical data since the structure of these economies is likely to change dramatically as a result of EMU» (p.1011). As a consequence, they proceed to the analysis, which they consider simply an application of the Lucas Critique, by claiming that «without denying the importance of the third and fourth criteria», which are the degree of labour mobility and the system of risk-sharing, «we focus on the first two OCA criteria» that is, the extent of trade and the similarity of the shocks and cycles (p.1011). On these premises, they conclude that «a country is more likely to satisfy the criteria for entry into a currency union ex post than ex ante» (p.1024).

The idea that monetary integration would induce economic and political convergence played an important role in leading some scholars to believe in the feasibility of the EMU with asymmetric architecture. Despite this, the possible implications of a monetary union without a fiscal union have been the subject of debate. In 1971, Nicholas Kaldor, commenting on the Werner Report, claimed that «it is a dangerous error to believe that monetary and economic union can precede a political union or that it will act (in the words of the Werner report) 'as a leaven for the evolvement of a political union which in the long run it will in any case be unable to do without'. For if the creation of a monetary union and Community control over national budgets generates pressures which lead to a breakdown of the whole system, it will prevent the development of a political union, not promote it» (Kaldor, 1980). Despite this debate, fiscal federalism has been excluded, as well as the introduction of a bailout clause or risk-sharing instruments. As a consequence, the only alternative has been the creation of an economic and monetary union with a centralised monetary policy and a decentralised fiscal policy; in other words, an EMU with asymmetrical architecture.

\section{The Conditions for Asymmetric Architecture: Rules and Policies}

Many mainstream economic theorists have confirmed the feasibility of asymmetric EMU architecture (Maes, 2002). Some, aware of the impossibility of forming a political union at least in the short term, have come to suggest the optimality of the EMU asymmetric architecture under certain conditions. 
For example, Alesina and Perotti (1998) analyse the risks and advantages of a centralised fiscal policy within a monetary and economic union. They observe that if countries are heterogeneous, the political risk associated with a centralised fiscal policy cannot be neglected. Indeed, there is a significant increase in uncertainty due to an increase in conflicts of interest among citizens of the different countries who can vote and are thus involved in the decision-making process. As a consequence, the economic advantages coming from a centralised fiscal policy risk being offset by possible political issues. Breuss (2000, p.103) confirms that «the Alesina and Perotti model allows one to justify the approach the EU has chosen in the Maastricht Treaty to create the policy framework of the EMU».

Beetsma and Bovenberg (2001) observe that institutional measures aimed at promoting the credibility of ECB monetary policy (e.g. by imposing an inflation target) tend to weaken fiscal discipline, and they conclude that «a monetary union without a fiscal union is optimal if both lack of commitment of monetary policy and lack of discipline of fiscal policy are serious. [...] These conditions for a monetary union but against a fiscal union are likely to be met in Europe» (p.203).

The awareness that the interests of the various European countries are potentially in conflict, and that governments are subject to moral hazard and freeriding problems, has led many scholars to consider it inappropriate and too expensive to expand the coordination of ex-ante fiscal policies, and sufficient for countries to guarantee fiscal discipline (Alesina et al., 2001; Beetsma and Bovenberg, 2001; Issing, 2002).

Fiscal rules, thanks to their supposed apolitical nature, seemed to be the best way to manage coordination and avoid political cycles in public finance, although «if not well-designed and implemented, they can also be a source of instability, in particular if they generate pro-cyclical fiscal policy» (Darvas et al., 2018, p.2). Uhlig (2003, p.54), following Kydland and Prescott (1977), claims that rules fixed by well-designed institutions are the solution to the coordination problem: «what is needed are good rules, and good rules are best implemented with a commitment technology. Good commitment technologies take the form of welldesigned institutions. Good examples for these institutions are the European Central Bank as well as the Stability and Growth Pact». The desire to release European institutions from possible political influences in order to guarantee peaceful relations between countries and to preserve their credibility is clear. Uhlig's (2003, p.55) proposal to relieve the ECOFIN of the task of imposing a penalty on countries that violate the SGP, and to ensure that these penalties are automatically imposed when the constraints are violated, is an excellent example.

These studies do not explain how the Eurozone countries can protect themselves from possible shocks and recessionary phases given the absence of risk sharing instruments, the constraint of fiscal discipline, and, consequently, the impossibility of resorting seriously to expansive fiscal policies. The concept of 

and their economic and political implications

expansive austerity, based on a German view in vogue in the 1980s and consistent with ordoliberalism, played a fundamental role in this regard. Giavazzi and Pagano (1990) analyse the possibility that fiscal retrenchment could be the premise for an expansionary phase. The idea is that the negative effects of spending cuts could be more than compensated by positive effects on expectations and more space for the expansion of the private sector. In order to verify empirically "how often the contractionary Keynesian effect of a spending cut prevails on its expansionary expectational effect» (p.76), the authors analyse two extreme cases in the 1980s, Denmark and Ireland. Briefly, the authors find that «there are cases in which the German view has a serious claim to empirical relevance» (p.105). It is clear that similar findings are the theoretical underpinning of austerity measures, but it is important to note that this German view seems suitable for small export economies able to compensate for the decrease in internal demand as a result of restrictive policies, such as Denmark and Ireland. The analytical focus on these two cases in the 1980s, however, is too narrow to be expanded to a heterogeneous group of countries such as the EMU. The other countries involved in Giavazzi and Pagano's (1990) analysis are also mostly the northern countries (e.g., Germany, Belgium, Netherland, France, United Kingdom) with a little reference to countries such as Italy and Spain. Despite this, other influential scholars have supported this view, which seemed to solve most doubts related to the stability of the asymmetric architecture of EMU.

This approach, which sees in the violation of fiscal discipline perhaps the only real threat to the stability of an optimal, despite asymmetric, EMU architecture, revealed the utilitarian conception of the European project. Mathieu and Sterdyniak (2013, p.191) note that «fiscal rules proponents argue that governments are not benevolent. Governments do not aim at optimising citizens' welfare but aim at being re-elected. Besides, each generation is selfish and does not care about the situation for future generations. Last, financial markets need to be reassured on the ability of governments to service debt. Each of these goals induces a specific rule». This confirms what economists were aware of: that the EMU was nothing more than a competitive arena in which the conflicting economic interests of the different countries faced each other, without trust, and without a real desire to share common goals or to be in solidarity with others. Without a political union but a common currency, the only goal of the EMU is to prevent member countries from taking advantage of the situation to the detriment of others. Fiscal discipline therefore plays a key role. This vision, however, sees a moral hazard risk only on the side of the most vulnerable countries, who are considered able take advantage of the credibility of the stronger member countries in order to reduce their fiscal discipline efforts. A partial vision unable to grasp such systemic risks that led to the European sovereign debt crisis. Despite all, this vision was able to survive long enough to affect the way in which the covid-19 emergency has been faced, years later. 


\title{
Roots and Consequences of the European Sovereign Debt Crisis
}

\author{
Understanding the Real Roots \\ of the European Crisis
}

European institutions and many mainstream scholars have developed a particular narrative aimed at explaining the causes and dynamics of the European sovereign debt crisis, coherently with the economic postulates that sustained the optimality of EMU architecture. While admitting the architectural flaws of the EMU, they believe that its asymmetry is not the principal responsible for the limited capacity of member countries to face the crisis. Indeed, the macroeconomic imbalances had to be resolved through microeconomic structural reforms aimed at improving the efficiency and flexibility of the markets. This would allow member countries to strengthen their competitiveness and resilience, but all this was not done because individual member states did not want to apply unpopular reforms. If this factor is added to the lack of adherence to fiscal discipline, then the responsibility of the member countries for the dynamics of the crisis is clear. This interpretation of the crisis has been persistent, as can be seen from the European Commission's EMU@10 report in 2008 up to the report $A$ blueprint for a deep and genuine economic and monetary union - Launching a European debate in 2012. The centrality of structural reforms and fiscal discipline are factors that we can also trace in the various Memorandums of Understanding or in the European Semester, as well as in efforts to increase the credibility of fiscal rules (e.g., fiscal compact) up to the most recent European reports.

There is no doubt that member countries must ensure sovereign debt sustainability to guarantee EMU stability, however, sovereign debt sustainability remains to be defined, and also how it can be guaranteed without compromising a country's growth prospects, and its role in the dynamics of the crisis. European convergence criteria set limits of 3\% for the public deficit/GDP ratio and $60 \%$ for the public debt/GDP ratio. Unfortunately, these limits are controversial and lack robust and widespread theoretical support. Indeed, «nobody has ever been able to give any plausible explanation of why these two figures were chosen» (Pasinetti, 1998b, p.104). One can only imagine that the answer is connected to the fact that when the nominal rate of growth of GDP is $5 \%$ (which seemed a reasonable figure to assume at the time, owing to, let us say, a $2 \%$ real rate of growth and a $3 \%$ rate of inflation), a situation in which the public debt/GDP ratio is $60 \%$ implies that the deficit/GDP ratio must be no higher than $3 \%$, if one wants to preserve a non-increasing debt/GDP ratio. [But] they represent a point on the 

and their economic and political implications

boundary to the «zone» in which the public debt to GDP ratio is either constant or decreasing. But clearly, within such a «sustainability» zone, the mentioned triplet of numbers $(3 \%, 60 \%, 5 \%)$ only represents one single point. There is an infinite number of other points - i.e. an infinite number of triplets - that share the same characteristics (Pasinetti, 1998a, p.19).

It is less easy to establish when, regardless of the circumstances, the level of the sovereign debt could be considered unsustainable. Indeed, «although sustainability of public finances has been discussed for more than a century now, it is still an imprecise concept. [...] there is no generally agreed upon definition of what precisely constitutes a sustainable debt position. [...] Debt sustainability can be regarded as a short-, medium-, or long-term concept, with the open question of how to define these horizons, and debt and deficits can be measured gross or net, including or excluding the liabilities of social security systems and other items» (Neck and Sturm, 2008, p. 1). The analysis becomes even more complex if we also consider, beyond public indebtedness, the role of private and total indebtedness, and the fact that «the public-debt bonds in circulation also fulfil a function similar to that fulfilled by the stock of money. They provide individuals and institutions with financial assets to hold" (Pasinetti, 1998a, p.33). What is often underestimated is the importance of the quality of public indebtedness, the circumstances that can lead to its increase (e.g., counter-cyclical spending) and the role of public investment in the development process of each European member country. Indeed, "cutting public investment has been a common response of European governments during the crisis, despite various studies highlighting the detrimental effects on growth» (Zuleeg and Schneider, 2015, p. 1). Unfortunately, both the Investment for Europe Plan (the so-called Juncker-Plan) and the investment clause under the SGP have failed. According to Zuleeg and Schneider $(2015$, p. 3) «the importance of social and other productive public investment should be reflected in the SGP. This could be achieved by introducing a Golden Rule, enabling governments - over the economic cycle - to borrow only to invest and not to fund current spending". This point of view is also shared by other scholars, such as Truger (2015).

Debt sustainability can be guaranteed in different ways, and compatibly with a country's growth path. It is now widely accepted that austerity policies did not bring about their desired effects, that expansive austerity did not work during the European crisis, and that the Maastricht parameters must be reviewed (Darvas, 2010). Many scholars also argue that fiscal discipline violations are not a factor underlying the crisis, which instead was caused by macroeconomic imbalances and the heavy dependence of some vulnerable member countries on foreign borrowing (Scharpf, 2011). These imbalances were also determined by the opportunistic behaviours of the core countries towards those of the periphery (Priewe, 2018; Eichacker, 2017). Pérez-Caldentey and Vernengo (2012) claim that «underpinned by a process of monetary unification and financial deregulation, core eurozone countries pursued export-led growth policies - or, more specifically, 'beggar thy neighbor' policies - at the expense of mounting disequilibria 
and debt accumulation in the periphery» (p.1) and that «noncore countries did not have the means to counteract and offset core countries' 'beggar thy neighbor' policies» (p.19). As noted by Gros (2013, p.503), at the outbreak of the financial crisis, «when the flows of capital dried up then both the governments and the private sector in these countries had difficulties in financing ongoing deficits and rolling over the existing stock of debt [...]. This created the impression that excessive fiscal deficits and high public debts had brought these countries to the brink of default». The strong involvement of German and French banks in the peripheral countries exposed their banking systems to the risk of default. It cannot be ruled out that the bailouts of some peripheral countries were nothing more than attempts to rescue the banking systems of the core countries (Nikolaidou, 2016). Thompson (2015, p.853) suggests that «the incentive for the German government both to present as German sacrifice initiatives that have in fact served the interests of German banks and to spread the cost of supporting those banks beyond German taxpayers was acute and consequential [...] these interests must be acknowledged in a way that has been absent in much discussion of the euro-zone crisis". The crisis seems to have shown that the failure to recognise that even the strongest countries could exploit their membership at the expense of others, was one of the most serious shortcomings of the analyses that supported the optimality of an asymmetric EMU architecture.

\section{Convergence through the Crisis?}

Lane (1993, p.54) notes that the rationale of the Maastricht rules «is that market discipline is inadequate to induce countries to pursue sound fiscal policies» and cites the Delors Report on the EMU, in which it is explicitly stated that «experience suggests that market perceptions do not necessarily provide strong and compelling signals. The constraints imposed by market forces might either be too slow and weak or too sudden and disruptive» (Delors Committee, 1989, p. 24). The monetary financing prohibition (i.e., the ECB cannot finance government spending), the 'no bailout clause' (i.e., the prohibition on assuming the debts incurred by another member country) and full responsibility for the risk of default lying with each member country, are some of the elements that should have guaranteed «positive feedback mechanisms which would ensure a stable economic and monetary system" and "encourage member states to keep their "own houses in order'» (Yiangou et al., 2013, p.227). However, this "governance through financial market discipline» has not worked properly (p.227). Indeed, markets «showed little willingness to punish deficit or debt levels above the Maastricht thresholds» so that "euro area member states received inappropriate signals about their future solvency, leading to deficit and debt levels not supported by underlying economic fundamentals» (p.228). The most surprising element is that this situation and the dramatic dynamics of the crisis favoured rather 

and their economic and political implications

than hindered further European integration. Yiangou et al., (2013, pp.234-235) concluded that «by encouraging countries to demonstrate policy credibility, the monetary financing prohibition leads to a gradual strengthening of supranational rules and institutions and a stronger role for the European Commission. [...] The monetary financing prohibition can therefore be seen as a form of 'tough love' that pushes deeper euro area integration and fills the 'gaps' in its original institutional design». In this regard, Schimmelfennig $(2014$, p.322) claims that «the triple sequence of financial crisis, debt crisis and Eurozone crisis has triggered an unprecedented politicization of European integration" and in particular the emergence of a technocratic supranational integration.

All this seems to indicate that although the market was unable to give appropriate signals to member countries prior to the crisis, it subsequently proved to be an efficient disciplinary tool. Tooze (2020) expresses this concept using the term debt market discipline. With reference to the European sovereign debt crisis, he claims:

That bond markets were so dominant with regard to weaker members of the eurozone at the height of the crisis in 2010-12 was anomalous. No doubt the financial situation of Greece was hopeless and that of Spain, Ireland and Italy difficult. But the pressure was massively amplified by self-imposed institutional constraints, strategic inaction by key European states, notably Germany, and a dangerous cat-and-mouse game played by the conservative leadership of the ECB under Jean-Claude Trichet. [...] The weak structure of collective fiscal discipline was supplement by the threat of bond-market terror. [...] The dysfunction resulted from political failure and, specifically, the tendency to substitute 'market discipline' for politics in Europe's incomplete monetary union. [...] in a crisis, what markets inflict is not so much rational and sustained discipline, but panic. Far from depoliticizing fiscal and monetary policy, the result was to stoke resentment on all sides.

Woodruff (2016, p.103) analyses the «political roots in the use of market panic as a tool to eliminate the space for democratic choice about economic policy». He claims that «there was no direct connection between data on budget deficits and growth prospects and the mood of the markets [...] There is no sense in which the austerity agenda was imposed by market forces; it was a political choice that governing by panic was used to implement» (p.104). Woodruff precises the mechanism that was working during the crisis:

Spiking interest rates on sovereign bond markets prompted a sense of crisis among European political leaders, who were well aware of the potentially disastrous impact on the banking system. And in each case, the ECB eventually used its power to create money to help calm markets. First, however, the ECB leadership implicitly or explicitly threatened to withhold its help unless policy or institutional changes implementing Brussels-Frankfurt priorities (especially labor market liberalization and fiscal austerity) were adopted. These threats were made credible by the rigid rules on the ECB's independence and mandate, and 
the prospect of vigorous German political and legal opposition to exceeding that mandate (p.98).

Similar observations are made by Ojala (2021, pp.207-208) who claims that «relying on the market as an autonomous disciplining mechanism, European authorities now enforced fiscal discipline [...] Such a blatant use of the market as a policy tool to subject governments to the will of the central bank rendered the ECB's power over the bloc increasingly apparent - and politicised».

Structural reforms are fundamental for economic and institutional convergence. According to some scholars, structural reforms aim to induce the weaker member countries to converge towards economic frameworks in which market mechanisms dominate. According to Nölke (2016, p.152), this sort of convergence is «the blueprint of the Troika reforms». Institutional convergence is certainly a difficult goal to achieve within the EU. The European integration process has shown that institutional convergence within the union was far more problematic than economic convergence (Schönfelder and Wagner, 2019; Alesina et al., 2017). Since institutional and economic convergence is an essential precondition for the political unification project, the asymmetric architecture of the EMU, fiscal rules and debt market discipline proved to be effective devices for accelerating this process during the crisis.

Varoufakis (2016, p.96), in his reconstruction of the political process at the basis of the EMU claims that: «François Mitterrand, and probably German chancellor Helmut Kohl too, knew that the common currency would spearhead unsustainable flows of money, from the surplus to the deficit countries. They could see that a large-scale crisis was inevitable. But they hoped that the crisis would create the political momentum toward a federal Europe». Many scholars and policymakers have argued, especially after the crisis, that political union is inevitable in the long-term (e.g., Bishop, 2011). Jean Monnet's prophecy (1976/1978, p.417) that «Europe will be forged in crises, and will be the sum of the solutions adopted for those crises" seems to support this analysis still further.

'Convergence through the crisis' may be, however, something more than a prophecy or an unpredictable evolution of the integration project. Indeed, it may be part of what Guiso et al. (2016) call 'Monnet's strategy' or 'Monnet's chain reaction theory'. These authors explain how the functionalist approach promoted by Jean Monnet and other functionalists within the European project aimed at transferring some policy functions to supranational institutions «which do not respond directly to voters [and] are deputized to push further the integration process»; this first step "creates a pressure for more integration through both positive and negative feedback loops". While positive feedback loops arise when policymakers and voters desire to deepen integration thanks to benefits observed from partial integration, negative feedback loops are found when «partial integration leads to institutional and economic inconsistences that will push further integration by forcing the introduction of the complementary reforms needed", especially because "dismantling the initial integration is costly». The existence of in- 

and their economic and political implications

stitutional and economic inconsistences seems not to be accidental: «technocrats typically start from narrow areas of expertise (e.g., coal, steel) where they have an informational advantage and voters and national politicians are not able to predict or anticipate the contradictions generated by these partial integrations, nor are interested in opposing them because they affect a limited number of voters. A leading example of this 'burning the ships' strategy is the euro» (p.252).

The connection between these institutional and economic inconsistences, or asymmetries, and the crisis, was confirmed by Guiso et al. (2016, p.253) who observed how some European founding fathers seem to have conceived the mechanism knowing that these inconsistences would lead to crises. These crises were seen as opportunities to force further integration which voters would have not favoured otherwise. In the words of Romano Prodi, one of these founding fathers, 'I am sure the euro will oblige us to introduce a new set of economic policy instruments. It is politically impossible to propose that now. But some day there will be a crisis and new instruments will be created'. [...] Padoa-Schioppa, one of the founding father of the euro, once said that the Economic and Monetary Union (EMU) has the same name of an ostrich-like Australian bird. 'Neither', he said, 'can go backwards'.

So far, it seems true that «Monnet's chain reaction theory delivered the desired outcome, albeit in a very non-democratic way» (p.292).

\section{The Future of European Asymmetries}

It remains to be clarified why it now seems so difficult to converge towards fiscal and political union. According to Varoufakis (2016, p.89), the technocratic imprint of the European institutions has not allowed the emergence of charismatic political figures capable of dragging the European populations towards political union as a response to the crisis: «inadvertently, Mitterrand and Kohl contributed to a technocracy revolving around a monetary union that eradicated the type of political leadership necessary to step in during a crisis and complete their creation".

The hostility that emerged between core and the periphery countries has been recognised as a sort of "second asymmetry" (Howarth and Verdun, 2020, p.288) that suggests a different explanation, strongly connected to the EMU's strong competitive nature, its lack of democratic legitimacy and its political imbalance due to power asymmetries between member countries (Eichacker, 2017).

As described by Farina (2020), Europe did not develop on the basis of a community spirit, but through a process of reconciliation of interests, which has been guided by the strongest countries. In this scenario, the rules aimed to make decisions appear apolitical that instead reflected the best political and economic 
outcome for the strongest countries. The breaking down of borders and the single market implied that competition between countries, and in particular market forces, had decreed the development of the European integration process. This approach penalises integration and favours national interests. Any help given to weak countries during the crisis was made only in the interest of the community and, ultimately, of the strong countries themselves. In such a context, many actions taken at European level have proved to be to the advantage of the politically and economically stronger countries.

It is well-known that there is a political imbalance in Europe. The EU has always been characterised by Franco-German leadership. Over time, the stronger countries have been able to influence the decisions of the European institutions. Haas et al. (2020, p. 332) admit that research suggests that «powerful countries seem to be better able to change Commission assessments of fiscal policy» and suggest that the episode of 2016 is a clear public example, when "Commission president Juncker admitted in 2016 that the Commission had given France leeway on fiscal rules 'because it is France'». One of the most serious yet neglected consequences of this political asymmetry was the interference of the strongest member countries in the economies of the most vulnerable member countries. The privatisation process is just one example of the consequences of this interference. Privatisations were another tool strongly recommended by creditor countries to reduce debt, and they were included in various Memorandums of Understanding. For example, to obtain the help it needed, Greece was forced in 2015 to agree to sell state assets and important infrastructure with the purpose of collecting 50 billion euros. There was explicit reference in the Memorandum of Understanding to the need to sell the Ports of Piraeus and Thessaloniki, but other assets were also put up for sale (e.g., the Helliniko Olympic complex, 14 regional airports, power and water companies, telecommunications and natural gas companies, etc.), despite opposition from the Greek population. It has not gone unnoticed that, as a consequence of the privatisation process, the major airports in Greece passed into the hands of a German public company, Fraport. Deutsche Telekom has also become the largest telephone company in Greece, a move in line with the company's goal of becoming the European leader in telecommunications. Other member countries have been led to similar privatisation processes (e.g., Portugal, Ireland and Cyprus) on the basis of the European Commission's conviction that the «privatisation of public companies contributes to the reduction of public debt, [and also] has the potential of increasing the efficiency of companies and, by extension, the competitiveness of the economy as a whole» (Vila and Peters, 2016, p.7). However, these claims seem to «ignore the evidence of recent privatisations which have more often led to reduced state revenue, increased corruption and poorer services. They also ignore the wage losses, redundancies and erosion of labour rights that have resulted from privatisation that have further exacerbated the economic crisis. The blindness of the Troika to the detrimental effects of short-term liquidation of state assets may be ideological in nature, but it is bolstered by the growth of a powerful 

and their economic and political implications

privatisation industry in Europe that profits immensely from these sales and actively lobbies for continued business» (p.5).

The asymmetry that emerged between core and periphery countries should not be interpreted as signalling a move away from the project of a political union, but as a phase defining the power relations between countries and designing the future leadership of the political union. In a sense, it seems that the idea of a political integration project in Europe, based on values of solidarity and sharing, has never really been shared by all European countries. Following the crisis, these divergent perspectives are starting to become clearer, as are their consequences. For example, Priewe (2018, p.75) reports that according to some scholars: "German policy should be geared to serve only own interests, like other countries are believed to do, but not 'moral values' like helping other countries to shrink their deficits".

European asymmetries (i.e., the asymmetric architecture of the EMU and the 'second asymmetry' that emerged between core and periphery) will probably not lead to the dissolution of the Eurozone, because this would be disadvantageous for European member countries. As noted by Helmut Schmidt «this is the great strength of the euro, that nobody can leave it without damaging his own country and his own economy in a severe way» (Marsh, 2009, p.255). However, some scholars fear that if the integration process is carried out without real approval from voters and if a Eurozone country decides to leave and its exit costs are not be as heavy as expected, then the Eurozone risks a dramatic meltdown (Guiso et al., 2016). Consequently, "to avoid this meltdown, there is a need of a more serious political discussion about the cost and benefits of unification. If the European project needs to regain consensus, it must be perceived as a choice, not as a forced outcome» (p.291).

Although these concerns are absolutely acceptable, asymmetric architecture lends itself to recurring crises that are likely to force fiscal and political convergence. What the Eurozone member countries must fear today is not mainly (or at least not only) the collapse of the EMU, but convergence, perhaps forced by the crisis that will follow the covid-19 emergency, towards a fiscal and political union without real democratic legitimacy within and between member countries.

\section{Conclusions}

We can now try to answer the three questions posed at the beginning of this paper.

Why was the EMU created with an asymmetric structure? The debate between the federalist and intergovernmental schools shows that the federalist project proposed a process of economic and political integration without a true proc- 
ess of democratic legitimacy. There are two basic reasons that led to support for this project. Politically, democracy would not guarantee a peaceful future in Europe because many dictatorships were born out of democratic processes. It was therefore necessary to undertake an integration project trying to build a European identity over time. Economically, the unification process promised economic benefits for all countries, although none were ready to give up their sovereignty to any great extent. Under these conditions, continuing the integration process left only one possibility: monetary union without fiscal and political union. Mainstream economics has tried to demonstrate the optimality and feasibility of an asymmetric architecture in the hope of institutional convergence in the longterm. EMU asymmetric architecture could be optimal under fiscal discipline and thanks to the role of expansive austerity. An interpretation that reveals a utilitarian vision of the European project and the awareness that the EMU is for the moment nothing more than a competitive arena. The idea that only the most vulnerable member countries can take advantage of EMU architecture leads to a strong focus on fiscal rules with important repercussions, not only for the interpretation and management of the crisis, but also in the way the covid-19 emergency is addressed.

What was the role of EMU architecture and European policies during the crisis? Market discipline was considerate inadequate to induce countries to guarantee sound fiscal policies. As a consequence, the Maastricht rules were introduced. It is well known that monetary financing prohibition, the 'no bailout clause' and the full responsibility for the risk of default have not promoted stability, especially during the crisis. Similarly, many scholars have underlined how the Maastricht rules do not have a robust economic justification. The way these controversial rules and European architecture have favoured rather than hindered a deepening of a technocratic supranational integration, however, caused many scholars to consider the political roots of the integration process. The crisis demonstrated that financial markets are an efficient disciplinary tool able to induce member countries through debt market discipline to respect the rules and apply structural reforms that are necessary for economic and institutional convergence, an important prerequisite for approaching a political union. EMU asymmetric architecture, with its instability and its rules, proved to be a suitable framework with which to create economic and institutional convergence through an economic crisis.

Do EMU asymmetries threaten the survival of the Eurozone? The true risk is not (or at least not only) the collapse of the Eurozone, but that EU member countries could converge (or be forced to converge as a consequence of crisis such as the one that will follow the covid-19 emergency) towards a fiscal and political union without democracy and fairness within and between countries. The conclusion seems to be that the fears of European architects that hostilities between European countries could result in new conflicts was well founded. The answer, however, should not have been to force a process of integration lacking democratic legitimacy, but to create the conditions for a political union starting from a political balance between member countries. 


\section{References}

Alesina, A., Blanchard, O., Galì, J., Giavazzi, F., \& Uhlig, H. (2001). Defining a Macroeconomic Framework for the Euro Area. Monitoring the European Central Bank, Vol.3. Centre for Economic Policy Research.

Alesina, A. \& Perotti, R. (1998). Economic risk and political risk in fiscal unions. The Economic Journal, 108(449), 989-1008.

Alesina, A., Tabellini, G., \& Trebbi, F. (2017). Is Europe an optimal political area? (No. w23325). National Bureau of Economic Research..

Baldwin, R., \& Wyplosz, C. (2009). The Economics of European Integration. McGraw-Hill.

Beetsma, R. M. W. J., \& Bovenberg, A. L. (2001). The optimality of a monetary union without a fiscal union. Journal of Money, Credit and Banking, 33(2), 179-204.

Bialasiewicz, L. (2020, July 13). National stereotypes in times of COVID-19: The «frugal four» and the «irresponsible South». openDemocracy. https://www.opendemocracy.net/en/can-europe-make-it/national-stereotypesin-times-of-covid-19-the-frugal-four-and-the-irresponsible-south/

Bickerton, C. J., Hodson, D., \& Puetter, U. (2015). The new intergovernmentalism: European integration in the post-Maastricht era. Journal of Common Market Studies, 53(4), 703-722.

Bishop, G. (2011). EU Fiscal Crisis: Forcing Eurozone Political Union in 2011? Searching Finance.

Breuss, F. (2000). Flexibility, fiscal policy and stability and growth pact. In Fourth ECSA-World Conference (pp. 98-126).

Cerutti, F. (2008). Why political identity and legitimacy matter in the European Union. In F. Cerutti \& S. Lucarelli (Eds.), The search for a European identity: Values, policies and legitimacy of the European Union (pp. 3-22). Routledge.

Closa, C. (2007). Why convene referendums? Explaining choices in EU constitutional politics. Journal of European Public Policy, 14(8), 1311-1332.

Connolly, B. (1995). The rotten heart of Europe. The dirty war for Europe's money. Faber \& Faber.

Dan, H. (2014). The euro zone-between fiscal heterogeneity and monetary unity. Transylvanian Review of Administrative Sciences, 43, 68-84. 
Darvas, Z. (2010). The case for reforming euro area entry criteria. Society and Economy, 32(2), 195-219.

Darvas, Z., Martin, P., \& Ragot, X. (2018). European fiscal rules require a major overhaul. Notes du conseil danalyse economique, 2, 1-12.

Delors Committee - Committee for the Study of Economic and Monetary Union (1989). Report on Economic and Monetary Union in the European Community. Office for Official Publications of the European Communities.

Duff, A. (2011). Federal Union Now. Federal Trust for Education and Research.

Dyson, K., \& Maes, I. (2016). Architects of the Euro: Intellectuals in the Making of European Monetary Union. Oxford University Press.

Eichacker, N. (2017). Financial Underpinnings of Europe's Financial Crisis: Liberalization, Integration, and Asymmetric State Power. Edward Elgar Publishing.

Farina, F. (2020, April 30). Solidarity in Europe, in what sense? [in Italian]. Menabò di Etica ed Economia, 125.

Follesdal, A., \& Hix, S. (2006). Why there is a democratic deficit in the EU: A response to Majone and Moravcsik. Journal of Common Market Studies, 44(3), 533-562.

Frankel, J. A., \& Rose, A. K. (1998). The endogeneity of the optimum currency area criteria. The Economic Journal, 108(449), 1009-1025.

Giavazzi, F. Pagano, M. (1990). Can severe fiscal contractions be expansionary? Tales of two Small European countries. In O. Blanchard \& F. Stanley (Eds.), NBER Macroeconomics Annual, (Vol. 5, pp. 75-111). MIT Press.

Gros, D. (2013). Foreign debt versus domestic debt in the euro area. Oxford Review of Economic Policy, (29)3, 502-517.

Guiso, L., Sapienza, P., \& Zingales, L. (2016). Monnet's error? Economic Policy, 31(86), 247-297.

Haas, J. S., D'Erman, V. J., Schulz, D. F., \& Verdun, A. (2020). Economic and fiscal policy coordination after the crisis: Is the European Semester promoting more or less state intervention? Journal of European Integration, 42(3), 327-344.

Hayward, J. (2012) Union without consensus. In J. Hayward \& R. Wurzel (Eds.), European disunion: Between sovereignty and solidarity (pp. 5-14). Palgrave Macmillan.

Hooghe, L. (2003). Europe divided? Élites vs. public opinion on European integration. European Union Politics, 4(3), 281-304. 

and their economic and political implications

Howarth, D., \& Verdun, A. (2020). Economic and Monetary Union at twenty: A stocktaking of a tumultuous second decade: Introduction. Journal of European Integration, 42(3), 287-293.

Issing, O. (2002). On macroeconomic policy co-ordination in EMU. Journal of Common Market Studies, 40(2), 345-358.

Kaldor, N. (1980). Further essays on applied economics. In Collected Economic Essays of Nicholas Kaldor (Vol. 6, pp. 187-220). Wiley.

Kydland, F. E., \& Prescott, E. C. (1977). Rules rather than discretion: The inconsistency of optimal plans. Journal of Political Economy, 85(3), 473-491.

Lane, T. D. (1993). Market discipline. Staff Papers (International Monetary Fund), 4O(1), 53-88.

Maes, I. (2002). Economic thought and the making of European Monetary Union. Edward Elgar Publishing.

Majone, G. (2005). Dilemmas of European integration: The ambiguities and pitfalls of integration by stealth. Oxford University Press.

Marsh, D. (2009). The Euro: The Politics of the New Global Currency. Yale University Press.

Masera, R. (2020). For a resilient, sustainable and inclusive recovery in Europe: Challenges and proposals in response to the pandemic crisis. Available at SSRN. http://dx.doi.org/10.2139/ssrn.3646959

Mathieu, C. \& Sterdyniak, H. (2013). Do we need fiscal rules? Revue de l'OFCE, 1(127), 189-233.

McKinnon, R. (1963). Optimum currency areas. The American Economic Review, 53(4), 717-725.

Monnet, J. (1978). Mémoires (R. Mayne, Trans.). Doubleday \& Company. (Original work published in 1976).

Moravcsik, A. (2002). Reassessing legitimacy in the European Union. Journal of Common Market Studies, 40(4), 603-624.

Mundell, R. (1961). A theory of optimum currency areas. The American Economic Review, 51(4), 657-665.

Neck, R., \& Sturm, J.-E. (Eds.) (2008). Sustainability of Public Debt. MIT Press.

Nikolaidou, E. (2016). The role of military expenditure and arms imports in the Greek debt crisis. The Economics of Peace and Security Journal, 11(1), 18-27.

Nölke, A. (2016). Economic causes of the Eurozone crisis: The analytical contribution of Comparative Capitalism. Socio-Economic Review 14(1), 141-161. 
Ojala, M. (2021). Doing away with the sovereign: Neoliberalism and the promotion of market discipline in European Economic governance. New Political Economy, 26(1), 203-215.

Pasinetti, L. L. (1998a). European Union at the end of 1997: Who is within the public finance «sustainability» zone? BNL Quarterly Review, 51(204), 17-35.

Pasinetti, L. L. (1998b). The myth (or folly) of the 3\% deficit/GDP Maastricht «parameter». Cambridge Journal of Economics, 22(1), 103-116.

Pérez-Caldentey, E., Vernengo, M. (2012). The euro imbalances and financial deregulation: a post-Keynesian interpretation of the European debt crisis. Levy Economics Institute of Bard College Working Paper, 702.

Priewe, J. (2018). A time bomb for the Euro? Understanding Germany's current account surplus (No. 59). IMK Study.

Scharpf, F. W. (2011). Monetary union, fiscal crisis and the preemption of democracy. Zeitschrift für Staats-und Europawissenschaften (ZSE)/Journal for Comparative Government and European Policy, 9(2), 163-198.

Schimmelfennig, F. (2014). European integration in the Euro crisis: The limits of postfunctionalism. Journal of European Integration, 36(3), 321-337.

Schlosser, P. (2019). Europe's New Fiscal Union. Palgrave Macmillan.

Schmidt, V. A. (2015). The Eurozone's crisis of democratic legitimacy. Can the EU rebuild public trust and support for European economic integration? (No. 015). Directorate General Economic and Financial Affairs (DG ECFIN), European Commission.

Schönfelder, N. \& Wagner, H. (2019). Institutional convergence in Europe. Economics: The Open-Access, Open-Assessment E-Journal, 13(3), 1-23.

Startin, N. \& Krouwel, A. (2013). Euroscepticism re - galvanized: The consequences of the 2005 French and Dutch rejections of the EU Constitution. Journal of Common Market Studies, 51(1), 65-84.

The Economist. (2020, March 26). How grasshoppers triumphed over ants in Europe. The old fiscal rules are no more. The Economist. https://www.economist.com/europe/2020/03/26/how-grasshopperstriumphed-over-ants-in-europe

Thompson, H. (2015). Germany and the Euro-zone crisis: The European reformation of the German banking crisis and the future of the Euro. New Political Economy 20(6), 851-870.

Tooze, A. (2020, May 25). Time to expose the reality of «debt market discipline». Social Europe. https://www.socialeurope.eu/time-to-expose-the-powerfulactors-behind-market-discipline 
Truger, A. (2015). Implementing the golden rule for public investment in Europe: Safeguarding public investment and supporting the recovery. WWWforEurope Policy Paper, No. 22, WWWforEurope.

Uhlig, H. (2003). One money but many fiscal policies in Europe: What are the consequences? In M. Buti (Ed.), Monetary and fiscal policies in EMU: Interactions and coordination (pp. 29-56). Cambridge University Press.

Vane, H. R. \& Mulhearn C. (2006). Interview with Robert A. Mundell. Journal of Economic Perspectives 20(4), 89-110.

Varoufakis, Y. (2016). And the weak suffer what they must? Europe's crisis and America's economic future. Nation Books.

Vila, S. T. \& Peters, M. (2016). The privatising industry in Europe. Issue Brief. Transnational Institute.

Weber, M. (2020, April 16). Eurobonds (or coronabonds) would not be costly for Northern euro area countries. LSE Business Review. https://blogs.Ise.ac.uk/businessreview/2020/04/16/eurobonds-orcoronabonds-would-not-be-costly-for-northern-euro-area-countries/

Weiler, J. (2001). European democracy and the principle of constitutional tolerance: The soul of Europe. In F. Cerutti, \& E. Rudolph (Eds.), A soul for Europe. On the political and cultural identity of the Europeans (vol. 1, pp. 33-54). Peeters.

Woodruff, D. M. (2016). Governing by panic: The politics of the Eurozone crisis. Politics \& Society, 44(1), 81-116.

Yarovaya, L., Matkovskyy, R., \& Jalan, A. (2020). The effects of a «black swan» event (COVID-19) on herding behavior in cryptocurrency markets: Evidence from cryptocurrency USD, EUR, JPY and KRW markets. Available at SSRN. https://doi.org/10.2139/ssrn.3586511

Yiangou, J., O'Keeffe, M., \& Glöckler, G. (2013). «Tough love»: How the ECB's monetary financing prohibition pushes deeper Euro Area integration. Journal of European Integration, 35(3), 223-237.

Zuleeg, F., \& Schneider, J. D. (2015). What role for social investment in the new economic governance of the Eurozone? European Policy Centre, Policy Brief, 10. 